International Review of Social History 43 (1998), pp. 203-233

(C) 1998 Internationaal Instituut voor Sociale Geschiedenis

\title{
Lines of Conflict: Labour Disputes in London, I790-I870*
}

\author{
DAVID R. GREEN
}

Summary: This paper examines labour disputes in London between 1790 and I870, based on a systematic coverage of working-class newspapers. Disputes were classified by type, cause and trade. Evidence exists for 294 disputes, the large majority of which were strikes. The incidence of disputes roughly paralleled cyclical and seasonal fluctuations in the economy. Wage claims were the main cause for conflict, although interpretation of such disputes needs to be related to price movements. The most serious disputes were associated with significant changes in control over employment and the labour process. Skilled and unskilled workers were involved in disputes, both taking advantage of specific circumstances to exert power at the workplace. The extent to which London was prone to disputes is discussed and tentative comparisons drawn with other regions in Britain.

\section{INTRODUCTION}

"Workmen dread a strike", Francis Place told the parliamentary select committee discussing the Combination Acts in I824, "I know well from experience that a strike is always a matter for serious consideration and never can be effectual unless it be really necessary." Strikes and other forms of labour dispute were deeply disruptive events for working-class communities, invariably bringing hardship to those involved, generating conflict with employers and always threatening to open rifts between strikers and those who remained at work. It is precisely because of the gravity of such issues for working-class communities that James Cronin has argued, "the record of strikes is clearly the critical source available for reconstructing the social history of the working class". ${ }^{2}$ Though strikes and turnouts may have been relatively unimportant in terms of the total number of contentious gatherings that occurred during the period, they nevertheless point to important

* The author would like to thank the anonymous referees for their very helpful comments and Dalia Magrill for her assistance with data collection.

I. Parliamentary Paper (hereafter PP), I824, V, Select Committee on Artizans and Machinery, p. 47.

2. James Cronin, Industrial Conflict in Modern Britain (London, I979), p. Io. 
ruptures in working-class experience. ${ }^{3}$ During the nineteenth century, most London workers to a greater or lesser extent were forced to confront the challenges of an overstocked labour market, the erosion of skill and the encroachment of unskilled labour. Collectively, these issues reflected the growing commodification of labour. Wage disputes, both in relation to rises, reductions and methods of payment, often reflected customary expectations and an antipathy to allowing the free play of market forces to dictate levels of remuneration. Attempts to prevent the employment of unapprenticed and unskilled labour, as well as resistance to changes in methods of payment, similarly reflected efforts to restrict the impact of market forces on employment opportunities. These issues were brought to the fore in labour disputes and for that reason such conflicts shed much light on working-class experiences and provide a crucial insight to the progress of and resistance to the commodification of labour under industrial capitalism.

In view of the significance of labour disputes, notably during the nineteenth century, it is perhaps surprising that we have such little systematic knowledge of their temporal and geographical incidence. ${ }^{4}$ Indeed, Kenneth Knowles's comment in 1952, that "The striker is unloved, unhonoured and unsung; above all, he is largely unstudied", still largely holds true in respect to early nineteenth-century Britain. ${ }^{5}$ This is mainly due to the problems involved in excavating the strike record prior to the annual publication of figures on labour disputes from I888 by the Board of Trade. ${ }^{6}$ Before that date we must rely on evidence gleaned from fragmentary sources, notably reports of disputes published in working-class newspapers. In view of the immense amount of work involved in such an exercise, labour historians have tended to focus either at a very general level or on particular strikes and individual trades over a limited time period. ${ }^{7}$ Those who have examined

3. The question of contentious gatherings is explored fully in Charles Tilly, Popular Contention in Great Britain $1758-1834$ (London, 1995). Tilly acknowledges that his data greatly underestimate the frequency of strikes and turnouts.

4. Most studies focus on the period after 1870 . See Cronin, Industrial Conflict in Modern Britain, pp. 197-205; idem, "Strikes I870-1914", in Christopher Wrigley (ed.), A History of British Industrial Relations I875-19I4 (London, 1982), pp. 74-98; idem, "Strikes and Power in Britain I870-1920", in L.H. Haimson and Charles Tilly (eds), Strikes, Wars and Revolutions in International Perspective (Cambridge, 1989), pp. 79-100; Michael Haynes, "Strikes", in John Benson (ed.), The Working Class in England I875-1914 (London, 1985), pp. 89-132; Peter Stearns, "Measuring the Evolution of Strike Movements", International Review of Social History, XIV (1974), pp. I-27. Exceptions to this are Andrew Charlesworth et al., An Atlas of Industrial Protest in Britain 1750-1990 (London, 1996); Lynn Lees, "Strikes and the Urban Hierarchy in English Industrial Towns, I842-190I", in James Cronin and Jonathan Schneer (eds), Social Conflict and Political Order in Modern Britain (London, 1982), pp. 52-73.

5. Kenneth Knowles, Strikes - A Study in Industrial Conflict (Oxford, 1952), p. xi.

6. See S.W. Creigh, "The Origin of British Strike Statistics", Business History, 24 (1982), pp. 95Io6.

7. See, for example, Keith Burgess, "Technological Change and the I852 Lockout in the British Engineering Industry", International Review of Social History, XIV (1969), pp. 215-236; Eric 
social protest as a whole have rarely tried to explore the regional dimension of industrial conflict. The exceptions include C.R. Dobson's work on eighteenth-century industrial conflicts, based largely on newspaper evidence, which stands alone as the only attempt to explore the broad regional and temporal dimensions of labour disputes, and Charles Tilly's analysis of contentious gatherings between 1758 and $1834{ }^{8}$ Recent work on the historical geography of industrial protest, though broad in terms of its temporal and spatial framework, also fails to provide a systematic analysis of the incidence of disputes prior to the late 1860 s, and then only for engineering workers. ${ }^{\text {? }}$

These gaps are important for two reasons. First, without a systematic analysis of labour disputes comparable in scope, for example, to the work on France by Shorter and Tilly, we can make little progress towards a comparative study of labour unrest in industrial societies. ${ }^{10}$ Without this comparative framework, it is all too easy for labour historians of different nationalities to claim "exceptionalism" for their particular account. ${ }^{\text {II }}$ Second, historians as well as geographers are increasingly aware of the importance of regional diversity in understanding economic change. ${ }^{12}$ The corollory of this is that labour historians also need to take account of differing regional experiences if they are to explain the nature and pattern of working-class protest. As recent cultural historians, such as Patrick Joyce and James Vernon, have pointed out, in any "meta-narrative" the significance of place cannot be overemphasized, particularly in the period prior to the availability

Hobsbawm, "Economic Fluctuations and Some Social Movements since I80o", in his Labouring Men (London, 1964), pp. I26-I57; Eric Hopkins, "An Anatomy of Strikes in the Stourbridge Glass Industry 1850-19I4”, Midland History, 2 (1973), pp. 2I-31; Michael Jenkins, The General Strike of I842 (London, 1980); Terry Parssinen and Iorworth Prothero, "The London Tailors' Strike of I834 and the Collapse of the Grand National Consolidated Trades' Union: A Police Spy's Report", International Review of Social History, XXII (1977), pp. 65-107; Lees, "Strikes and the Urban Hierarchy in Industrial Towns", pp. 52-72; Richard Price, Masters, Unions and Men: Work Control in Building and the Rise of Labour 1830-19I4 (Cambridge, 1980); B. Silver, "Labor Unrest and World-Systems Analysis: Premises, Concepts and Measurement", Review, I8 (1995), pp. 7-34.

8. See John Stevenson, Popular Disturbances in England 1700-1832 (London, 1992); Tilly, Popular Contention in Great Britain; C.R. Dobson, Masters and Journeymen (London, 1980).

9. See Charlesworth et al., Atlas of Industrial Protest in Britain.

Io. See Edward Shorter and Charles Tilly, Strikes in France I830-I968 (Cambridge, 1974).

II. For a discussion of exceptionalism see James Cronin, "Neither Exceptional nor Peculiar: Towards the Comparative Study of Labor in Advanced Society", International Review of Social History, XXXVIII (1993), pp. 59-75.

I2. There is a growing literature on regional economic change during the Industrial Revolution. See Maxine Berg and Pat Hudson, "Rehabilitating the Industrial Revolution", Economic History Review, 2nd ser., XLV (1992), pp. 38-39; Pat Hudson, The Industrial Revolution (London, 1992), pp. IOI-I32; Edward Hunt, "Industrialisation and Regional Inequalities: Wages in Britain 1760I9I4", Journal of Economic History, XLVI (1986), pp. 935-966; J. Langton, "The Industrial Revolution and the Regional Geography of England", Transactions of the Institute of British Geographers, new ser., 9 (1984), pp. 145-167. 
of cheap mass transport and rapid communication when the locality and region provided the primary context for personal experience. ${ }^{\mathrm{I3}}$

Whilst it is beyond the scope of a single paper to address the question of national comparisons, nevertheless it is possible here to explore the regional dimension of industrial conflict. This paper examines the evidence of labour disputes in London from 1790 to 1870 based largely on a detailed and systematic analysis of the working-class press. ${ }^{14}$ To some extent the start and end points of the period are arbitrary, although the former allows comparison with Dobson's work on eighteenth-century industrial disputes whilst the latter links with research on the later period. ${ }^{\text {Is }}$ The main issues addressed focus on the timing and causation of labour disputes and examines the trades involved. It is hoped that the findings will provide a benchmark against which other national and regional studies can be compared. London, after all, contained the largest concentration of industrial workers in Britain at the time and metropolitan labour disputes were therefore of significance both at a regional as well as at a national level.

\section{LABOUR DISPUTES AND STRIKES}

Distinguishing labour disputes from other forms of social protest is important if we are to understand the role of working-class resistance to the commodification of labour. In this respect, two issues need to be examined relating, first, to the distinction between labour disputes and other forms of social protest, and, second, to the forms which such disputes took. By labour dispute what is meant here is any form of resistance to the treatment of labour as a commodity, either at the workplace or in the labour market as a whole. More specifically, as Silver has pointed out, the former focuses on the point of production itself and is mainly concerned with the labour process in terms of the prolongation, intensification or degradation of work practices, whilst the latter is more concerned with labour market questions, notably the level of wages and unemployment. ${ }^{16}$ Of course, the distinction between labour disputes and other forms of working-class protest is to some extent false; the individuals involved often overlapped, as indeed did Francis Place, and the institutions which sustained one, including trade unions,

13. This is the message that comes through strongly from Patrick Joyce, Visions of the People (Cambridge, 1994), esp. pp. 279-304 and James Vernon, Politics and the People (Cambridge, 1993). See also Catharina Lis and Hugo Soly, "Neighbourhood Social Change in West European Cities", International Review of Social History, XXXVIII (1993), esp. pp. 25-30.

I4. London is here taken to be the registration district used in the I85I census which subsequently became the area controlled by the Metropolitan Board of Works and later administered by the London County Council.

15. See note 2 above. It is hoped to continue coverage of disputes up to 1888 when the Board of Trade commenced publication of information on strikes.

16. See the discussion in Silver, "Labor Unrest and World-Systems Analysis", pp. I2-I6. 
often supported the other. Furthermore, working-class ideology informed the actions of strikers as well as those involved in other forms of social protest and for that reason alone we should be wary of drawing too strong a distinction between labour disputes focused on work and the workplace and those struggles which sought more generally to improve conditions by influencing the social wage. Although the focus here is on the former, it would be unwise to distinguish too strongly between work-based protests and struggles of a more general nature - an understanding of both is necessary if we are to appreciate the historical dimensions of working-class protest.

In terms of the forms taken by labour disputes, it is useful to draw a distinction between "open" forms, such as strikes, riots or deputations, and "hidden" forms of protest, such as absenteeism, sabotage and go-slows. Clearly, the balance between open and hidden forms depended largely on the context of industrial relations and in particular on the legislative framework surrounding labour disputes. Where strikes were illegal, for example, it is reasonable to expect a higher level of hidden protest, although by definition these forms are far more difficult to detect in the historical record. Irrespective of form, however, all protests can be defined with reference to two criteria: they are purposeful, i.e. aimed at achieving a specified outcome, and collective, that is undertaken by a group of workers rather than an isolated act by one individual. These criteria differentiate such protests from personal grievances that surface from time to time between workers and their employers and which do not necessarily have any wider significance for understanding the relations between capital and labour.

Although strikes are by no means the only form of labour protest, in terms of frequency and numbers of workers involved, they were the most significant form of industrial conflict. Strikes can be defined with reference to three main criteria. ${ }^{17}$ First, a strike involves a cessation of work, thereby distinguishing it from other forms of protest such as go-slows or overtime bans. Second, in order to differentiate them from mass resignations of the workforce, strikes are temporary phenomena and workers fully expect to return to their jobs subject to a satisfactory conclusion being reached with their employer. Finally, a strike is calculative in the sense that it expresses a grievance or attempts to force a claim on the part of workers against their employers. Causation is therefore an essential element although it must be recognized that amidst the accusations and counter-accusations it is often difficult to establish the exact points of disagreement.

Having defined labour disputes, there remains the not inconsiderable problem of establishing their existence in the historical record. Writing in I880 George Bevan commented that "Strikes, numerous as they are, have been so imperfectly chronicled [...] that the labour of getting at the simple

17. This definition is borrowed from the work of Richard Hyman, Strikes (London, 1984), p. I7. 
fact of their occurrence has been very considerable" ${ }^{\text {I8 }}$ Those who have since tried to reconstruct the strike record have tended to rely on newspaper evidence and this paper follows a similar approach. ${ }^{19}$ The research here relies mainly on evidence from a systematic investigation of the working-class press in London, together with full coverage of The Times for the entire period. ${ }^{20}$ As Appendix I shows, from the mid-I82os until the end of the period, no year passed without the publication of at least one working-class newspaper in the capital. Prior to that date press coverage was less complete although other sources of information about labour disputes, notably the Francis Place papers and the parliamentary reports on the repeal of the combination laws in 1825 , provided a wealth of information. The importance of using a variety of sources to "capture" labour disputes is borne out is by comparing The Times with other papers. In 1853 , for example, twenty disputes were reported in London of which six appeared in The Times alone, seven in Reynolds Newspaper, five in both and two others elsewhere. As this example makes clear, over-reliance on one source alone is likely to lead to serious underestimation of the number of disputes. To avoid this problem, the database of labour disputes examined here has been constructed wherever possible by consulting at least two newspapers for each year.

Over and above the importance of cross-checking individual newspapers, other issues arise. In the early decades of the century, especially prior to the reduction of stamp duties from $6 d$ to $\mathrm{I} d$ in $\mathrm{I} 836$, working-class papers were often ephemeral affairs, hampered by financial constraints and sometimes lasting for little more than a few months. This was particularly true during the battle over the unstamped press during the i830s when papers appeared and disappeared from one month to the next. ${ }^{21}$ Nevertheless, whilst newspapers themselves came and went, there was much greater continuity in terms of editors and publishers. During the I830s, for example, Henry

I8. G. Bevan, "The Strikes of the Past Ten Years", Journal of the Royal Statistical Society, 93 (1880), p. 36.

19. See Silver, "Labor Unrest and World-Systems Analysis", pp. 23-24.

20. The working-class press is here defined loosely to include those newspapers which explicitly referred to working-class interests in their title, subtitle or motto. Such papers were usually published weekly on a Sunday, the day on which workers had most time to read. The appendix lists the newspapers consulted. See Virginia Berridge, "Popular Sunday Newspapers and Mid-Victorian Society", in G. Boyce, J. Curran and P. Wingate (eds), Newspaper History from the Seventeenth Century to the Present Day (London, 1978), pp. 247-264; idem, "Content Analysis and Historical Research on Newspapers", in A. Harris and A. Lee (eds), The Press in English Society from the Seventeenth to the Nineteenth Centuries (London, 1986), pp. 20I-218; David R. Green, "From Artisans to Paupers" (unpublished Ph.D. thesis, University of Cambridge, 1984), pp. 422-427; R.K. Webb, The British Working Class Reader (London, I955), pp. 32-34. See also J. Dangler, "The Times (London) and the New York Times as Sources on World Labor Unrest", Review, I8 (1995), pp. $35-47$.

2I. For the tortuous history of working-class papers in the I820s, see Prothero, Artisans and Politics, pp. 183-209. For the history of the unstamped press in the I830s, see Patricia Hollis, The Pauper Press (London, 1970). 
Table I. Circulation figures for selected weekly newspapers

\begin{tabular}{lccr}
\hline Title & Year & $\begin{array}{c}\text { Number of } \\
\text { stamps issued }\end{array}$ & $\begin{array}{c}\text { Weekly } \\
\text { circulation }\end{array}$ \\
\hline Weekly True Sun & 1837 & 484,551 & 9,318 \\
Northern Star & 1839 & $1,851,000$ & 35,596 \\
Reynolds Newspaper & 1851 & 151,050 & 2,905 \\
” & 1850 & 275,250 & 5,293 \\
& 1853 & $1,501,750$ & 28,880 \\
\hline
\end{tabular}

*Weekly circulation $=$ number of stamps issued $/ 52$

Sources: PP I839 XXX, Returns showing the number of stamps issued for newspapers; PP I852 XXVIII, Return relative to the number of stamps issued to newspapers in the United Kingdom; PP I852 XXVIII, Return relative to the number of stamps issued to newspapers in the United Kingdom; PP I854 XXXIX, Return relative to the number of stamps issued to newspapers in the United Kingdom.

Hetherington, treasurer of the London Working Men's Association and a staunch Chartist, edited three newspapers: Penny Papers for the People (January to July I83I), the Poor Man's Guardian (July i83I to December 1835), and the London Dispatch (September I836 to October 1839). Julian Harney, who had been a shop boy with Hetherington during the early I830s, subsequently published the Red Republican in I850, which in turn was replaced by the Friend of the People until 1852 when it merged with the Northern Star and was renamed the Star of Freedom, still with Harney involved. Therefore, although papers themselves frequently changed titles, and sometimes disappeared, there was much greater continuity in relation to those involved and editorial direction and this in turn meant that the coverage of labour disputes remained an important element throughout the period. This continuity was also enhanced from 1836 with the reduction of stamp duty, after which time titles changed less frequently. Thus, from 1838 until its demise in the early I850s, the Northern Star was the most widely read working-class paper and provided the main source of information on labour disputes during that period. From I85I Reynold's Newspaper gained importance and by the mid-I850s had taken over as the largest working-class newspaper in the country. The circulation figures shown in Table I, based on the number of stamps issued, provide an indication of the importance of these working-class newspapers as a means of capturing details of disputes in the capital. ${ }^{22}$ Inevitably gaps in coverage remain but from the 1820 con-

22. The number of stamps was usually an overestimate, but gives a rough guide to circulation: See A.P. Wadsworth, "Newspaper Circulation I800-1914", Transactions of the Manchester Statistical Society (1955), pp. I-37. It must not be forgotten that readership was many times larger than the actual number of papers printed. 
siderable continuity existed, if not in the titles of the newspapers themselves then at least in the personnel involved, and this in turn helped to maintain a steady interest in reporting labour disputes.

Despite this continuity, gaps in the reporting of labour disputes inevitably occur for a variety of reasons. Reports of labour disputes themselves took many forms, including news items, letters and court reports. Where disputes involved large numbers of workers, or where ringleaders were dealt with harshly by the courts, interest was high and reports appeared frequently. It is likely, of course, that more routine forms of conflict, smaller-scale disputes and hidden forms of protest may have been ignored, but the fact that the papers themselves were printed and sold in the capital probably meant that information on metropolitan disputes was probably more readily available than that for more distant parts of the country. ${ }^{23}$ Heightened awareness of labour disputes, such as during the debates surrounding repeal of the Combination Acts in I825, for example, could also affect the likelihood of a strike appearing in the papers, whilst at other times similar disputes may have gone unreported. In view of these issues, this research makes few claims in terms of recording the absolute number of disputes. Nevertheless, in view of the systematic coverage of contemporary newspapers, in all probability the evidence reflects the changing level and broad nature of industrial disputes in the capital and as such provides the most complete analysis of labour unrest in a specific region in Britain prior to $1888 .{ }^{24}$

\section{RECORDING LABOUR DISPUTES}

For the period from 1790 to 1870 information was collected for each labour dispute in London relating to the type, trade involved, numbers on strike, start and end dates, duration, primary and secondary causes, location of

23. For a discussion of the issues raised by the reporting of social conflicts, see D. Snyder and W. Kelly, "Conflict Intensity, Media Sensitivity and the Validity of Newspaper Data", American Sociological Review, 42 (1977), pp. I05-I23; M.H. Danziger, "Validating Conflict Data", American Sociological Review, 40 (1975), pp. 570-584; M. Milne, "Strikes and Strike Breaking in North-East England I8I5-44: The Attitude of the Local Press", International Review of Social History, XXII (1977), pp. 226-240; James Corrigan, "Strikes and the Press in the North-East I815-44: A Note", International Review of Social History, XXIII (1978), pp. 376-38I.

24. The database of labour disputes was compiled from a systematic reading of the major workingclass newspapers, such as the Northern Star and Reynolds Newspaper, together with a complete coverage of The Times based on Samuel Palmer's index. Palmer's index was searched for any reference to strikes, lock-outs, turnouts, combinations, trade unions, wages, prosecutions for conspiracy, or mention of individual trades. According to Engels, the Northern Star was "the only sheet which reports all the movements of the proletariat", cited in The Condition of the Working-Class in England (1892; this ed., London, 1973), p. 230. The full list of newspapers is provided in Appendix I. Gaps in the coverage of working-class newspapers were filled by referring to The Times and other newspapers. Other contemporary sources, including Parliamentary Papers and the Francis Place Newspaper collection held at the British Library, were also consulted, as too was the Webb Trade Union collection held in the British Library of Political and Economic Science. 
outbreak and outcome. Disputes were classified by type according to whether they were a strike, lock-out, deputation of workers, petition, legal proceedings or union meeting that referred to a specific work-based grievance. Outbreaks of rioting that focused on workplace grievances, though rare in London, were also recorded..$^{25}$ Causes were classified into three broad criteria, depending on whether they related to wages (wage rise, wage reduction, methods of payment, price lists), control of the labour process (hours of work, methods of work, use of machinery) or employment (the use of non-unionists, unskilled labour). ${ }^{26}$

In total, evidence exists for 294 labour disputes in London, of which at least 234, comprising 80 per cent of the total, were strikes or prosecutions of workers for combining during the course of a strike. Of the remainder, forty-two were court actions over specific issues, nearly half of which occurred during the apprenticeship campaign of I8IO-I8I3, nine were lockouts by employers, and the rest were a miscellaneous collection of various forms of protest, including deputations to employers, petitions and isolated instances of rioting and machine breaking. Whilst the amount of information for individual disputes varied, it was possible to establish the primary cause for at least 83 per cent of the total. Start dates of disputes were normally pinpointed to within a week, although information on end dates and outcomes was less common. Details of the numbers of workers must be treated as no more than a rough approximation. For the reasons discussed above, it is impossible to estimate what percentage of all disputes in London is covered by this database, although the detailed coverage of working-class newspapers and systematic cross-checking with The Times index suggests that the total may be treated as a reasonably good approximation to the truth. Nevertheless, erring on the side of caution, attention here is focused on establishing the timing of disputes, trades involved and the causes of conflict rather than any quantitative assessment of the size and shape of disputes, as explored elsewhere. ${ }^{27}$

25. In their study of labour unrest in the world economy, Silver $e t$ al. distinguish between general strikes, strikes, riots, unemployed protests, protests or disputes, demonstrations, lock-outs and other actions. See B. Silver et al., "Data Collection Instructions", Review, I8 (1995), pp. 195-20I. The classification adopted here is broadly comparable with that of Silver $e t$ al., particularly in the way in which strikes, riots and lock-outs are distinguished from other forms of disputes.

26. Frequency is normally taken to be the number of strikes per Ioo,ooo workers in the appropriate trade, size is measured by numbers of workers involved whilst duration is measured in terms of the number of man-days lost through stoppage. See Shorter and Tilly, Strikes in France, p. $5 \mathrm{I}$. Unfortunately, the fragmentary nature of the data meant that it was difficult to establish any quantitative comparisons with other studies.

27. For a discussion on the shape of disputes see Edward Shorter and Charles Tilly, "The Shape of Strikes in France 1830-1960", Comparative Studies in Society and History, 13 (1971), pp. 6086; idem, Strikes in France, pp. 49-7I. See also Stearns, "Measuring the Evolution of Strike Movements". 


\section{THE TIMING OF DISPUTES}

\section{Cyclical}

It is generally accepted that the timing of disputes is largely dependent on the state of the economy, although there is some debate about the precise nature of the relationship. ${ }^{28}$ In contrast to pre-industrial forms of social protest, which tended to occur at peak times of distress, more "modern" forms of protest, such as strikes, which entailed greater levels of formal organization, tend to cluster during upturns in the business cycle. ${ }^{29}$ In expansionary phases both union and personal finances increase, thereby providing the resources needed to last through a strike. High labour demand reduces the possibililty of replacing those on strike and correspondingly provides alternative employment opportunities for the strikers themselves. With full order books employers were more likely to agree to demands, although paradoxically this might have tempted them to yield to strike threats more frequently and so possibly reduce the overall number of strikes. Conversely, low demand and slack employment during downturns were not conducive to strikes, although such conditions provided employers with an opportunity to reduce wages and alter conditions of work. In similar fashion, the cause of strikes tended to vary according to the economic cycle. As George Potter, the builders' leader, noted, during periods of peak demand workers were more likely to embark on aggressive actions in pursuit of improvements in wages and conditions. By contrast, resistance to wage cuts, encroachments on trade privileges, the use of cheap labour and alterations to customary practices were more frequent during downturns when

28. Silver, "Labor Unrest and World-Systems Analysis" points out that a pro-cyclical relationship is more characteristic of western European countries than the USA. See ibid., pp. 8-9. See also P. Edwards, Strikes in the United States I88I-1974 (Oxford, 198I), pp. 6I-67; A. Hansen, "Cycles of Strikes", American Economic Review, II (192I), pp. 6I6-62I; E.H. and D.B. Jurkat, "Economic Functions of Strikes", Industrial and Labor Relations Review, 2 (1949), pp. 527-545; T. Levitt, "Prosperity Versus Strikes", Industrial and Labor Relations Review, 6 (1953), pp. 220-226; Jack Skeels, "Measures of U.S. Strike Activity", Industrial and Labor Relations Review, 24 (1971), pp. 515-525; A. Rees, "Industrial Conflict and Business Fluctuations", Journal of Political Economy, LX (1952), pp. 371-382; A. Weintraub, "Prosperity Versus Strikes: An Empirical Approach", Industrial and Labor Relations Review, I4 (1966), pp. 23I-238. Long wave theorists also posit a relationship between periods of labour militancy and social and economic restructuring. See Ernest Mandel, Long Waves of Capitalist Development (London, 1980), pp. 37-6r; James Cronin, "Stages, Cycles and Insurgencies: The Economics of Unrest", in Terence Hopkins and Immanuel Wallerstein (eds), Processes of the World System (London, I980), pp. IOI-II8; Silver, "Labor Unrest and WorldSystems Analysis", pp. 9-I2.

29. In the context of Britain, Europe and the USA after 1850 Eric Hobsbawm first noted how industrial conflict and mass unionism coincided with economic upturn: see Hobsbawm, Labouring Men, p. 132, and also D. Sapsford, "A Time Series Analysis of U.K. Industrial Disputes", Industrial Relations, I4 (1975), pp. 242-249. 
employers' positions were stronger and their desire to alter the labour process more easily implemented..$^{30}$

Figure I plots the outbreak of disputes in London which peaked at five points in I8IO-I8I2, I825, I834, I853 and I865-I867. The first wave of unrest was associated primarily with the tight labour market and high inflationary pressures of the Napoleonic wars. Opposition to the employment of nonapprenticed workers, and, in the case of bespoke tailoring, to the use of women, was widespread..$^{3 \mathrm{I}}$ Strikes over wage rises to combat inflation also occurred in a variety of trades, including the tailors who downed tools on at least five occasions during the war. ${ }^{32}$ The next strike wave took place in I825, the year in which the Combination Acts were repealed and at the peak of the post-war expansionary boom. Not surprisingly, workers took advantage of this set of circumstances to strike for improved conditions, but by the end of that year the financial bubble had burst and strikes thereafter were largely defensive actions against wage cutting.

The crisis of I 825 was the start of a long downswing during which labour disputes, with some notable exceptions, were relatively infrequent. The strike wave of I834 was associated entirely with Robert Owen's Grand National Consolidated Trades' Union (GNCTU), rather than with any significant upturn in the economic cycle. Indeed, in terms of the labour market, conditions were far from ideal for a strike and this, perhaps as much as the internal dissension that racked the GNCTU, was responsible for the failure of the strike wave. ${ }^{33}$ In the aftermath of defeat and in the context of the prolonged economic downturn of the late I830s and I840s, union activity declined and workers proved reluctant to strike.

This period of quiet was brought to an abrupt halt at mid-century as the economy began to recover and as workers began to reorganize. ${ }^{34}$ In 1852 London engineers struck as part of a national dispute organized by the newly formed Amalgamated Society of Engineers, and in the following year, as inflation rose and as the Crimean War boosted demand for labour, the

30. George Potter, "Strikes and Lockouts from the Workmans' Point of View", Contemporary Review, I5 (1870), pp. 35-37. Potter himself was the builders' leader during the nine hours campaign in 1859-1860. He was also President of the London Working Men's Association and later editor of the Beehive newspaper.

3I. See PP, I8I2-I8I3, IV, Select Committee on the several petitions [...] respecting the apprentice laws. Prosecutions of masters who evaded the apprenticeship laws were undertaken on behalf of journeymen by William Chippendale, suggesting that the legal campaign was coordinated by a trades' committee. See T.K. Derry, "The Repeal of the Apprenticeship Clauses of the Statute of Apprentices", Economic History Review, 3 (193I-1932), pp. 67-87; David R. Green, From Artisans to Paupers (Aldershot, 1995), pp. I2I-I25; Prothero, Artisans and Politics in Early Nineteenth-Century London, pp. 5I-6I.

32. See British Library Place Collection, Additional Manuscript, 27834, f. I08.

33. See Parssinen and Prothero, "The London Tailors' Strike", pp. 65-107.

34. See Edward Hunt, British Labour History I8I5-I9I4 (London, I98I), pp. 25I-252, 254-255. 


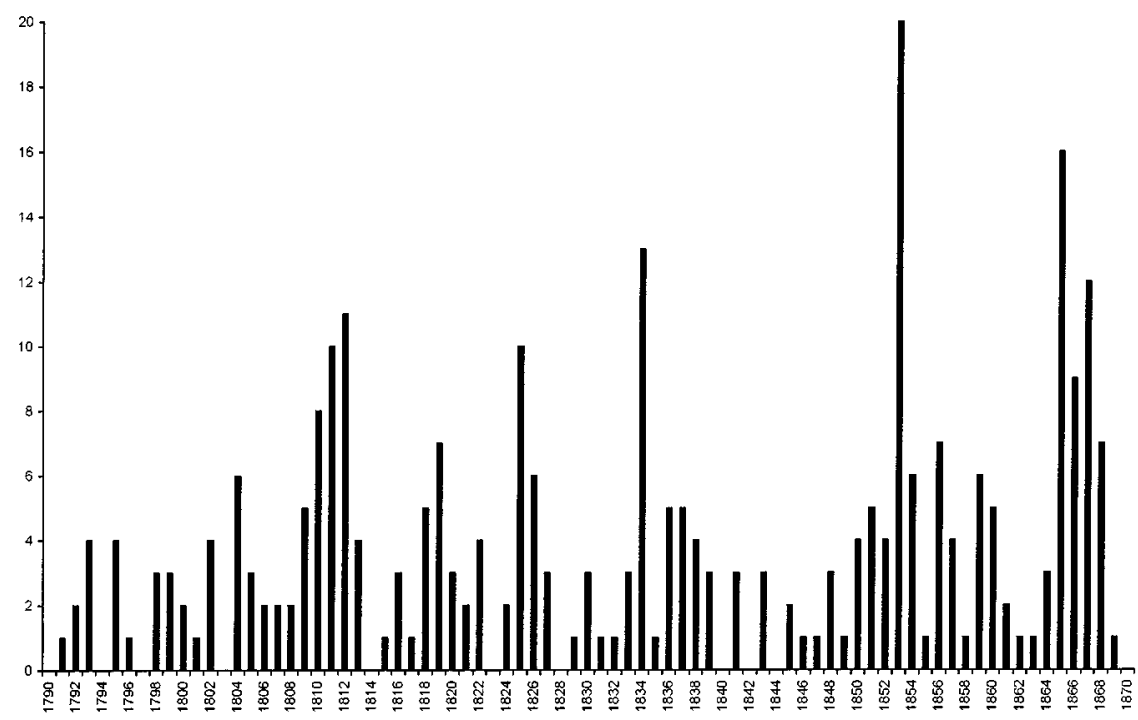

Figure I. Labour disputes in London, I790-1870

number of disputes escalated..$^{35}$ At least fourteen of the twenty strikes in 1853 were in pursuit of higher wages in an attempt both to counter inflation and to claw back reductions that had been imposed in previous years. ${ }^{36}$ The final strike wave in the mid-I86os was also associated with high demand arising from the American Civil War and disputes initially focused on higher wage claims. However, demand fell with the end of the war and by late I866 labour militancy had similarly declined. Strikes thereafter were primarily defensive actions to prevent the erosion of wages and the degradation of customary working practices.

\section{Seasonal}

The cyclical nature of industrial conflict was paralleled by seasonal fluctuations in the timing and causation of disputes. Evidence for the UK as a whole for the period 1893-1971 suggests that strikes tended to cluster in the spring (May) and autumn (October). ${ }^{37}$ According to Sapsford, this pattern can be explained with reference to the seasonality of demand in particular trades, the annual round of wage negotiations and the reluctance of workers

35. For the 1852 engineering strike see Burgess, "Technological Change and the I852 Lockout"; Charlesworth et al., Atlas of Industrial Protest in Britain, pp. 72-73, 76.

36. London workers were not alone in striking in 1853 . Elsewhere, for example, The Times, noted strikes by seamen, dock labourers, iron workers and cotton spinners.

37. Sapsford, "Time Series Analysis of U.K. Industrial Disputes", pp. 243-245. 


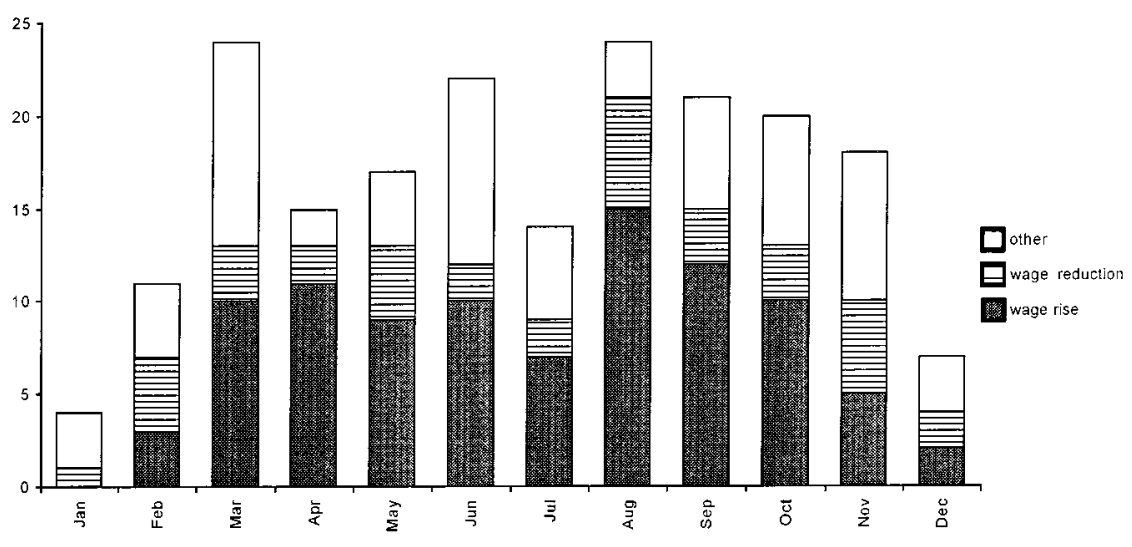

Figure 2. Seasonal incidence of strikes, 1790-I870

to strike prior to the summer and Christmas holidays. In the nineteenth century, the first factor was of greatest significance, particularly given the highly seasonal nature of the metropolitan economy in which few trades, if any, were untouched by fluctuations in supply and demand..$^{38}$ The building trades, for example, operated different summer and winter scales of pay and hours of work. In the I830s and I840s, bricklayers were paid $6 d$ less per day in winter compared to summer. ${ }^{39}$ The London Season, which was at its height during late spring and early summer, provided bespoke tailors, shoemakers, hatmakers and dressmakers with their busiest period. With some exceptions, notably the docks, spring and summer were the busiest seasons in terms of employment as well as the cheapest in terms of the cost of living.

Workers were more likely to strike when conditions were most promising and for this reason they tended to favour spring and summer. The seasonal incidence of strikes, shown in Figure 2, reflects this pattern, particularly in relation to disputes over wage rises, which peaked in March and April as the spring season got under way, and again in August and September as the autumn rush commenced. By contrast, other strikes were spread more evenly throughout the year, although as a proportion of all disputes those concerning wage reductions tended to peak between November and February. With demand low in many trades, employers had relatively little to lose by enforcing wage cuts whilst workers were reluctant to strike in view of the higher cost of living in winter arising from the need to provide extra heat and light. Thus, one way or the other, both sides tried to make the most of any temporary advantages brought about by seasonal fluctuations. 


\section{THE TRADES}

The frequency with which specific trades embarked on labour disputes depended broadly on three factors: size of the workforce, the level of skill and power at the workplace. The figures in Table 2 show that the number of disputes broadly reflected the size of the workforce, although in some trades the incidence of disputes was disproportionately high in relation to the share of employment. Trades that were significantly over-represented included builders, shoemakers, hatmakers, printers, coopers and shipbuilders. By contrast, furniture, food and transport were under-represented according to the numbers employed. Size alone, therefore, cannot account for the number of disputes and other factors need to be considered, notably the role of skill and power at the workplace.

The propensity for building workers (bricklayers, builders, carpenters, masons, painters, plumbers and glaziers) to strike can be explained partly by the nature of the work and partly by high levels of employment fostered by urban expansion, particularly from the I850s. The nature of building itself and the scale of operations, particularly on large construction projects, meant that different groups of workers were required to cooperate and this

Table 2. Labour disputes by trade, I790-I870

\begin{tabular}{lccc}
\hline Trade & Number & $\begin{array}{c}\text { Percentage of } \\
\text { disputes }\end{array}$ & $\begin{array}{c}\text { Percentage of male } \\
\text { non-white collar } \\
\text { employment, } \\
1851^{*}\end{array}$ \\
\hline Building & 65 & 22.1 & 13.8 \\
Clothing (total) & 58 & 19.7 & 11.9 \\
$\quad$ shoemaking & $(34)$ & $(11.6)$ & $(6.5)$ \\
tailoring & $(15)$ & $(5.1)$ & $(6.7)$ \\
$\quad$ hatmaking & $(9)$ & $(3.1)$ & $(0.7)$ \\
Dock work & 20 & 6.8 & $* 6$ \\
Engineering and metal work & 20 & 6.8 & 10.0 \\
Transport & 20 & 6.8 & 2.9 \\
Printing and bookbinding & 18 & 6.1 & 0.8 \\
Coopering & 12 & 4.1 & 0.9 \\
Shipbuilding & 12 & 4.1 & 5.3 \\
Furniture & 10 & 3.4 & 10.8 \\
Food & 8 & 2.7 & 1.8 \\
Silkweaving & 7 & 2.4 & 1.3 \\
Leather & 7 & 2.4 & 34.0 \\
Others & 37 & 12.6 & \\
Total & 294 & 100.0 & \\
\hline
\end{tabular}

Source: See text for discussion of sources. Workforce figures from i85i census.

* This total covers all non-white-collar employment and comprises the census registration categories VII, X, XI, XII, XIII, XIV and XV.

** The census did not include a separate category for dock labour. 


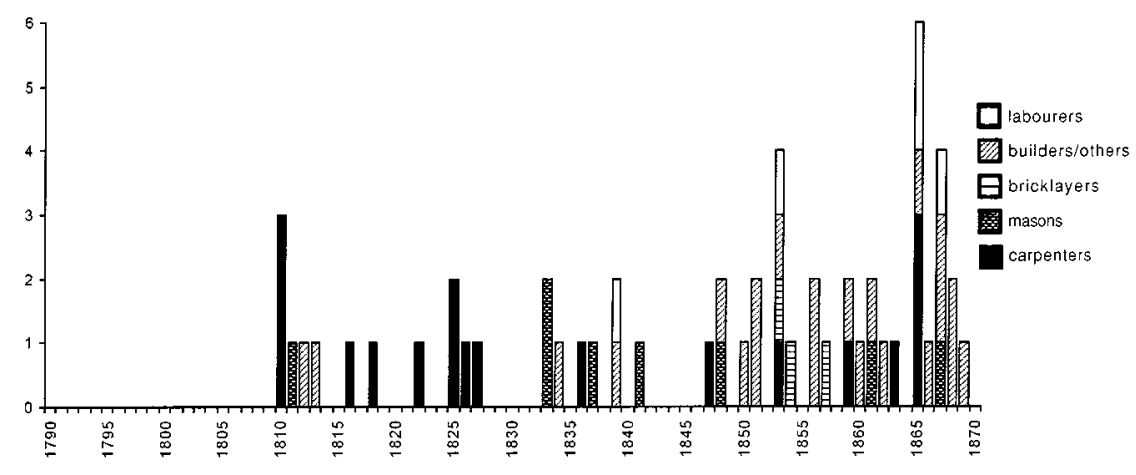

Figure 3. Labour disputes in the building trades, $1790-1870$

made it more likely that a dispute in one branch would spread to others. ${ }^{40}$ Furthermore, since bricklayers, carpenters, painters, plumbers and glaziers sought to maintain rough parity in pay and conditions, changes in one trade would rapidly be transmitted to the rest. On many occasions, therefore, specific claims or grievances spread from one branch to encompass the building trades as a whole.

As Figure 3 illustrates, no disputes were recorded before I8Io, possibly because the relatively low level of construction during the Napoleonic wars was not conducive to labour disputes but also because traditional means of wage arbitration still continued in the trade ${ }^{4 \mathrm{I}} \mathrm{W}$ ith the exception of a wage strike in I8IO, disputes between then and I8I3 concerned the apprenticeship campaign and as such reflected the problems faced by artisans in general rather than any specific grievances within the building trades. However, as market forces replaced paternalist arbitration in determining wage settlements, and as labour became increasingly commodified, so strikes became more common. A tit-for-tat pattern emerged in which workers took advantage of peaks in the building cycle to press for improvements and employers sought to claw back some of the concessions during downturns.

This pattern of disputes, however, also hinted at important structural changes in the industry reflecting the rise of large general contractors and the spread of piece-work and subcontracting. ${ }^{42}$ With the spread of fixed price tendering for major projects, pressures mounted on wages and working practices and as construction gathered pace from mid-century, conflicts between capital and labour became more common. With the memory of high unemployment still fresh in the mind, builders were amongst the first

40. The significance of the workplace in understanding the pattern of militancy in the building trades is dealt with in Price, Masters, Unions and Men, pp. 55-76.

4I. Place Collection, Additional Manuscript 27799, ff. I2O-I23.

42. E.W. Cooney, "The Origins of the Victorian Master Builders", Economic History Review, 2nd ser., VIII (1955), pp. 167-176; Price, Masters, Unions and Men, pp. 22-27. 
to address the problems of the commodification of labour in the labour market, as witnessed by their campaign during the 1850 os for shorter hours of work. ${ }^{43}$ Several of these disputes were large affairs focused on the major construction firms. Following demands for a nine-hour day in 1859, for example, eighty-eight of the largest building firms locked out their workforce ${ }^{44}$ In I86I the focus of disagreement shifted to the method of payment and a second city-wide dispute erupted over the change from daily to hourly payment. ${ }^{45}$ Although this strike failed to halt the introduction of the hour system, defeat was not disastrous and trade union membership continued to grow. In the early I860s, the newly formed Amalgamated Society of Carpenters and Joiners drew most of its membership from London, as too did the Operative Bricklayers Society and the Friendly Society of Operative Stonemasons. ${ }^{46}$ Building workers thus ended the period in a stronger position than they had been at the start; buoyed by high demand and backed by effective unions they spearheaded labour militancy in London after I850.

Another group of workers to benefit from London's growth were those employed in transport including seamen, cabmen, omnibus drivers and railway engine drivers. Widely differing circumstances in each trade make it difficult to generalize about the course of industrial conflicts. However, most of the disputes occurred after I850, reflecting both the growing importance of transport in the metropolitan economy as well as the need to establish rules of work in new occupations. Railway engine drivers and firemen, for example, were completely new trades and many of the early disputes in that branch reflected the initial sorting out of rules between the railway companies and the drivers. ${ }^{47}$ The amalgamation of omnibus companies in midcentury also created problems of integration and when customary practices came under attack by the newly formed London General Omnibus company in 1857 a third of the workforce struck. ${ }^{48}$ Greater regulation of cab drivers, including new rules over the lighting of cabs and plying for trade at railway stations, also met with stiff resistance in 1867 and $1868 .{ }^{49}$ Whilst questions of pay were often at the root of such disputes, new working practices and rules were also important catalysts for conflicts in each of these trades. However, in common with the builders, urban expansion bolstered

43. Reynolds Newspaper, 23 November 1856; PP 1867 XXXII, Royal Commission on Trade Unions, q. 2606; Price, Masters, Unions and Men, pp. 38-53.

44. G. Shaw Lefevre and T. Bennett, "Account of the Strike and Lock-out in the Building Trades in London 1859-60", in Trades Societies and Strikes, National Association for the Promotion of Social Science (1860), pp. 52-76; Webb Trade Union Collection (hereafter Webb Coll.) E, series A, vol. II, f. I45; Price, Masters, Unions and Men, pp. 50-53.

45. Webb Coll. E, series A, vol. Iо, f. Io8; ibid., vol. I3, f. 205-206.

46. PP I868-1869 XXXI, Royal Commission on Trade Unions, appendix J, pp. 659-660, 672.

47. See, for example, Northern Star, I9, 26 August I848, 17, 24, 31 August, 30 November, I4 December I850, 4, II January I85I.

48. The Times, I2 May I857; see also Anon, The Employer and the Employed (London, I852).

49. Reynolds Newspaper, 8 December 1867; Beehive, 25 July, 29 August, 5, I2 September I868. 
workers in these trades and they too ended the period in a position of relative strength.

By contrast workers in the clothing trades, including hatmakers, shoemakers and tailors, faced mounting difficulties. At the start of the century each trade had a reputation for labour militancy with strong unions and a well-established network of houses of call..$^{\circ}$ However, from the I820s and I830s pressures to lower production costs increased and the wholesale sector expanded at the expense of bespoke production, ushering in a greater division of labour, the spread of piece-work and the introduction of large numbers of cheaper, unskilled workers. ${ }^{\text {II }}$ Artisans found it increasingly difficult to resist this influx and accordingly were unable to prevent the erosion of pay and conditions. Disputes in the clothing trades are shown in Figure 4 and whilst conditions differed in each branch, the general pattern of unrest is clear. Most disputes occurred prior to the formation of the Grand National Consolidated Trades' Union in I834. From I790 to I834, there were thirty-five disputes with only eighteen strike-free years. Up to the late I820s clothing workers, and tailors in particular, had successfully defended their status at the workplace. Indeed, earlier in the century Francis Place had described the tailors' union as "a perfect and perpetual combination", noting how they had succeeded in raising wages five times between 1795 and $1813 .{ }^{52}$ Thereafter, conditions deteriorated as unskilled workers flooded into the trade and ready-made clothes, shoes and hats undercut bespoke production. An early indication of the mounting pressures came in 1827 when tailors engaged in making waistcoats struck against the employment of women, and again in I830 over the refusal of masters to pay the traditional double rate during periods of mourning..$^{53}$ The debacle in I834 over the GNCTU, which the tailors had used as a vehicle for pursuing their own sectional grievances, merely highlighted their weakness and in the aftermath of defeat the house of call system, so admired by Place earlier in the century, was destroyed. ${ }^{54}$ Despite efforts to revive the tailors' union during the I840s

50. Green, Artisans to Paupers, pp. 95-96, I28; I. Prothero, "London Chartism and the Trades", Economic History Review, 2nd ser., XXIX (197I), pp. 207-210.

5I. See Sidney Chapman, "The Innovating Entrepreneurs in the British Ready-Made Clothing Industry", Textile History, 24 (1993), pp. 5-25; Green, Artisans to Paupers, pp. 160-173.

52. PP 1824 V, Select Committee on Artizans, p. 45.

53. Red Republican, 23 November 1850 ; Parssinen and Prothero, "The London Tailors' Strike", p. 70.

54. Houses of call were places, usually public houses, in which workers from a particular trade met at regular intervals for the purposes of conviviality and for discussing trade matters, including the organization of disputes. Such places also operated as informal labour exchanges and nodes of working-class organization. Members of a trade could register themselves available for employment and masters in need of workers could apply to a house of call for those next on the register. Trade union members from other parts of the country could also apply to a house of call belonging to their particular trade and receive board and lodging whilst in search of work. Representatives from separate houses of call were often linked together in a wider network of trade organization. As such houses of call also functioned as nodes of trade union activity and were frequently at the 


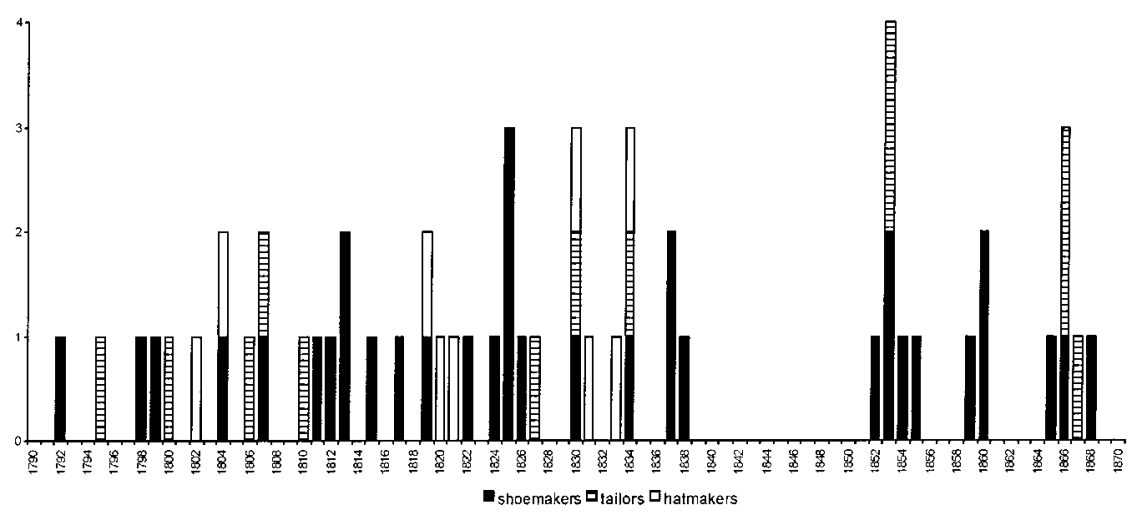

Figure 4. Labour disputes in the clothing trades, I790-I870

little was achieved and it was not until 1866 that bespoke workers regained sufficient strength to embark on a further campaign of workplace militancy. 55

The pattern of industrial militancy was similar in both hatmaking and shoemaking. Hatmakers also experienced difficulties from the 1820 and I830s when changes in fashion began to disrupt customary practices and patterns of employment. With the introduction in the I830s of cheaper "stuff" hats in place of more expensive fur hats, less skilled workers began to be employed in greater numbers, thereby undermining the position of "fair" men and eroding the power of the hatters' union. The situation was exacerbated in the I84Os as silk hats became more fashionable. Under these conditions, it proved difficult for hatters to sustain their long-established tradition of militancy. Strikes in I830 and I833 for wage rises both ended in failure and, as with the tailors, disputes thereafter were rare and the hatmakers more acquiescent. ${ }^{56}$

By contrast, shoemakers appeared able to sustain a high level of labour militancy throughout the period. However, this owed more to the fragmen-

centre of labour disputes. They also had important social functions in conviviality and support for workers fallen on hard times. For fuller discussion of houses of call see R.A. Leeson, Travelling Brothers (London, 1979).

55. The two strikes that took place in 1853 both involved seamstresses in the slop trade, the first calling for higher wages and the second in protest at the introduction of sewing machines: see Reynolds Newspaper, II, 25 September, 2 October 1853, The Times, 16, 23 September I853. For later disputes see Reynolds Newspaper, I2 November, 24 December I865, I, 8 April I866, I4, 28 April, I2 May 1867; Beehive, I3, 20, 27 April, I, 8, 22, 29 June 1867, The Times, 23, 27 April 1867.

56. J. Burn, A Glimpse at the Social Condition of the Working Classes during the Early Part of the Present Century (London, I868), p. 42. A further sympathy strike took place in I834 at Christy's, one of the foremost hatmaking firms in London and the provinces, when provincial masters refused to employ members of the hatmakers' union: see Reply of the Journeymen Stuff Hatters of London (London, I834). 
tation of the trade than to the proverbial political radicalism of shoemakers or the strength of trade unions. ${ }^{57}$ At the start of the period, shoemakers' unions were exceptionally strong in all branches of the trade..$^{58}$ As early as I804 London masters had complained that a combination existed throughout nearly the entire trade and that it was common for strikes to occur against anyone who refused to dismiss "scamps", or non-society men, from their employment. ${ }^{59}$ In 1812 , however, a strike succeeded in raising wages for West End shoemakers but not for those in the City and henceforth different rates of pay prevailed between the two districts. This split did little to foster unity within the trade and it was certainly more difficult thereafter to coordinate labour militancy. ${ }^{60}$

The shoemakers' position was further undermined after $18 \mathrm{Is}$ by falling demand, lower prices and growing competition, particularly from Northampton. Those strikes that occurred were mainly defensive actions to protect earnings and stem the influx of unskilled workers. Their participation in the GNCTU, like that of the tailors, was predicated on this basis and although shoemakers' trade unionism survived the debacle, it nevertheless remained on the defensive for the remainder of the decade. ${ }^{61}$ During the I840s weak demand put an end to this low level of militancy, although it was evident from Mayhew's interviews with "society" shoemakers that trade unionism had not disappeared entirely. However, when conditions improved in the early I850s, it was workers in the "strong" trade, located mainly in the City and East End and making cheap boots and shoes for the wholesale and export markets, rather than the traditional West End artisan who took up the mantle of labour militancy.

Whilst the fortunes of clothing workers declined, those employed in rapidly expanding trades, such as engineering and printing, managed to maintain or improve their situation. Engineering workers were well known for their militancy: the Combination Act of 1799 had been promoted specifically to deal with the London millwrights and the campaign to repeal the apprenticeship laws in I8I4 had similarly been organized by large engineering employers as a means of weakening combinations in the trade. ${ }^{62}$ The

57. See Eric Hobsbawm and Joan Scott, "Political Shoemakers", in Eric Hobsbawm, Worlds of Labour (London, 1984), pp. I03-130.

58. The branches included mens' and ladies' shoes, together with coarser boots made in the "strong" trade.

59. St James Chronicle, I-3 November 1804; A. Aspinall (ed.), The Early English Trade Unions (London, 1949), pp. 76-77.

6o. PP i824 V, Select Committee on Artizans, pp. 137-138, I45; J. O’Neill, "Fifty Years' Experience of an Irish Shoemaker in London", St Crispin, I (I869), p. 314; Henry Mayhew, The Morning Chronicle Survey (Firle, 1980), vol. 3, pp. I46-I47.

6I. Operative, 4, I8, 25 November, 9, 23 December I838, 20 January I839.

62. Memorial of Machinists and Engineers (London, I8I3), Public Record Office HO 42/133; Anon,

The Origin Object and Operation of the Apprentice Laws (London, I814). See also Edward Thompson, The Making of the English Working Class (London, 1968), pp. 27I-273. 
decline of traditional skills, however, was more than matched by the development of new ones which ensured that journeymen were able to retain considerable power at the workplace. Even defeat in the national strike of I852 failed to undermine their position. ${ }^{63}$ The preservation of skill and expanding demand provided a similar basis for militancy amongst compositors and pressmen. Indeed, the celebrated prosecution of workers from The Times in I8ro was the catalyst that had persuaded Francis Place of the need to repeal the Combination Acts. ${ }^{64}$ In turn the preservation of artisan status at the workplace and the willingness to strike in pursuit of claims, meant that workers in both trades were able to maintain relatively high wages throughout the period. ${ }^{65}$

The significance of handicraft skill, as well as seasonal pressure of work, were important in explaining the frequency of labour disputes amongst the coopers, who although relatively few in number nevertheless maintained a strong tradition of artisan independence. ${ }^{66}$ Shipwrights also relied on their skilled status, as well as the pressure of work, to pursue their claims. In the first quarter of the century, when demand for London ships was at its height, the Thames shipwrights led by John Gast were amongst the best organized and most militant workers in the capital. However, as fortunes in the industry waned, so the power of shipwrights weakened and they proved extremely reluctant to embark on strikes after $1825 .{ }^{67}$

One group of workers who also seemed reluctant to strike were those employed in furniture making. Disputes in the trade were often confined to a single workshop and as a result were perhaps more difficult to detect. ${ }^{68}$

63. For the subsequent history of engineering trade unionism see H. Southall, "Towards a Geography of Unionization: The Spatial Organization and Distribution of the Early British Trade Unions", Transactions of the Institute of British Geographers, new ser., I3 (1988), pp. 466-483. Further discussion of engineering workers in London can be found in Geoffrey Crossick, $A n$ Artisan Elite in Victorian Society (London, 1978).

64. The Times, 2I July, 26 September, 9 November I8Io.

65. See J.W. Crompton, "Report on Printers' Strikes and Trades Unions since January I 845 ", in Trades Societies and Strikes, National Association for the Promotion of Social Science (1860), pp. 77-92; E. Howe and H. White, The London Society of Compositors (London, 1948); A.E. Musson, The Typographical Association (London, 1954), pp. 3-26, 76-85. Wage rates can be found in A. Bowley and G. Wood, "The Statistics of Wages in the United Kingdom During the Last Hundred Years (part V): Printers", Journal of the Royal Statistical Society, 62 (I899), pp. 708-715; idem, "The Statistics of Wages in the United Kingdom During the Last Hundred Years (part XII): Engineering and Shipbuilding", Journal of the Royal Statistical Society, 68 (1905), pp. 563-614.

66. Coopers were notoriously independent: see R. Gilding, The Journeymen Coopers of East London (Oxford, 197I), pp. 49-82; A. Henderson and S. Palmer, "The Early Nineteenth-Century Port of London: Management and Labour in Three Dock Companies I800-1825”, Research in Maritime History, 6 (1994), pp. 43-44.

67. See Sidney Pollard, "The Decline of Shipbuilding on the Thames", Economic History Review, 2nd ser., 3 (1950), pp. 72-89; Prothero, Artisans and Politics in Early Nineteenth-Century London, pp. 46-49, I63-17I, 217.

68. See David Blankenhorn, "Our Class of Workmen: The Cabinet Makers Revisited", in J. Harrison and J. Zeitlin (eds), Divisions of Labour (Brighton, 1985), pp. I9-46. 
Industrial relations may also have been smoothed by the continued use of an agreed book of prices, which persisted longer in cabinet making than in many other trades. ${ }^{69}$ Furthermore, the fact that relatively little capital was needed to set up in the trade meant that journeymen could avoid confrontation by themselves becoming small masters. Mayhew, for example, estimated that little more than $\mathfrak{E}_{3}$ or $\mathfrak{E}_{4}$ was required to set up as a "garret master" in cabinet making. ${ }^{70}$ Perhaps for this reason the cabinet makers' unions never reached sizeable proportions, especially in the poorly paid East End sector, and without a well-supported union it was extremely difficult to undertake, let alone sustain, strikes. ${ }^{7 \mathrm{I}}$

Whilst handicraft skill provided a basis for labour militancy in many trades, the same could not be said of dock labourers and coal heavers, where physical strength was the main requirement. As a result there were few barriers to entry and the casualized dock labour market in particular was notoriously overstocked. On a visit to the docks, Henry Mayhew noted the fierce struggle for employment: "Presently you know, by the stream pouring through the gates and the rush towards particular spots, that the "calling foremen' have made their appearance. Then begins the scuffling and scrambling forth of countless hands high in the air, to catch the eye of him whose voice may give them work" ${ }^{72}$ The frequency with which dock workers and coal heavers struck, however, is a reminder that power at the workplace derived from a combination of circumstances and not just the possession of handicraft skill. In the age of sail, when the pattern of arrivals in port was dictated by the winds, seasonal pressure to unload ships provided a window of opportunity for workers to press their claims. Winter, for example, was the best time for coal heavers to strike, and they did so on several occasions during the I840s when pressures on wages and changes in the method of employment threatened their position. ${ }^{73}$

Desperation rather than the erosion of skill or opportunistic motives

69. A dispute that took place in 1837 concerning the London Cabinet Makers Union Book of Prices of I8II suggests that it was still in use. The price book ran to over 600 pages and took nearly three years to complete, and consequently there was understandable reluctance to revise it: see London Mercury, 5 February 1837.

70. Mayhew, Morning Chronicle Survey, vol. 3, p. I30.

7I. E. Jones, Notes to the People (London, I85I-1852), vol. I, p. 657. In 1850 the Friendly Society of Operative Cabinet Makers had a membership of 455, rising to 528 in I860: see H. Southall, D. Gilbert and C. Bryce, Nineteenth Century Trade Union Records, Historical Geography Research Series, 27 (1994), p. 83.

72. Henry Mayhew, London Labour and the London Poor (186I-I862; this ed. London, 1968), vol. 3, p. 304 .

73. Nominally, coal heavers had to be registered to be eligible for work. However, pressures on costs from the I840s stemming from competition with the railways, as well as changes in hiring practices arising from an act of 1843 , encouraged employers to lower wages and to use unregistered men, and these changes were the main reasons for the outbreak of strikes: see Mayhew, London Labour, vol. 3, pp. 243-26o. 
drove the silk weavers to strike. No group of workers suffered more from structural decline than did Spitalfields weavers and their willingness to strike, which on rare occasions extended to machine breaking and the cutting of silk on the looms, reflected forlorn efforts to halt the inexorable slide in their fortunes. Four of the seven weavers' strikes occurred between I819 and 1829, reflecting the depth of depression during those years and the struggles over the repeal in I824 of the protective mantle afforded by the Spitalfields Act. ${ }^{74}$ Disputes after that time were miserable affairs undertaken reluctantly by the weavers against a small number of "unprincipled" masters responsible for cutting wages. ${ }^{75}$ In practice, such actions were ineffective in halting the spiral of decline and by mid-century silk weaving was synonymous with poverty. As one weaver ruefully remarked to Henry Mayhew in I849, "It's been a continuation of reductions for the last twenty-six years, and a continuation of suffering for just as long" ${ }^{76}$ Not surprisingly, under such adverse circumstances the number of protests faded along with the weavers' fortunes.

Finally, it is worth noting disputes in other important London trades. Given their quantitative importance, the food trades are under-represented by the figures in Table 2. Indeed, disputes mainly concerned the bakers' short time movement in the I850s and I860s rather than any general upsurge of militancy. In part the limited number of strikes may have reflected the lack of opportunity: the food trades were not as seasonal as dock work nor were they as skilled as the artisan trades. In addition, many of those involved in the manufacture of food tended to be self-employed or worked in small groups. Although there were some large employers in the capital, the $185 \mathrm{I}$ census shows, for example, that 92 per cent of butchers and 96 per cent of bakers employed less than five men each, making them amongst the most fragmented trades in the capital. ${ }^{77}$ As a result, workers experienced few of the direct conflicts between capital and labour that characterized other London trades such as building, printing or engineering, in which large firms were of greater importance.

\section{CAUSATION}

Plotting the incidence of disputes and the trades involved is relatively easy compared to the task of establishing the causes of conflict. In the heat of a dispute accusations and counter-accusations between strikers and employers

74. Statesman, 5 January I820; Trades Newspaper, I April ı827; see also John Clapham, "The Spitalfields Act 1773-1824”, Economic Journal, 26 (1916), pp. 459-471; Dorothy George, London Life in the Eighteenth Century (London, I966), pp. 188-196.

75. PP I856 XIII, Select Committee on Masters and Operatives, q. 2255, 2269-2270; PP I860 XXII, Select Committee on Masters and Operatives, q. 42I-426, 430, 447.

76. Mayhew, Morning Chronicle Survey, vol. I, p. 57.

77. See Green, Artisans to Paupers, p. 3 I. 
Table 3. Causes of labour disputes, 1790-1870

\begin{tabular}{|c|c|c|c|c|c|c|c|c|c|c|}
\hline \multicolumn{3}{|c|}{ Wages } & \multicolumn{3}{|c|}{ Employment } & \multicolumn{3}{|c|}{ Labour process } & \multicolumn{2}{|c|}{ Other/Unspecified } \\
\hline Cause & No. & $\%$ & Cause & No. & $\%$ & Cause & No. & $\%$ & Cause & No. \% \\
\hline Wage rise & 116 & 39.4 & $\begin{array}{l}\text { Unskilled } \\
\text { labour }\end{array}$ & 26 & 8.8 & $\begin{array}{l}\text { Hours of } \\
\text { work }\end{array}$ & 22 & 7.5 & $\mathrm{Otl}$ & $\begin{array}{ll}19 & 6.5\end{array}$ \\
\hline $\begin{array}{l}\text { Wage } \\
\text { reduction }\end{array}$ & 53 & 18.0 & $\begin{array}{l}\text { Non- } \\
\text { unionist }\end{array}$ & 13 & 4.4 & $\begin{array}{l}\text { Methods } \\
\text { of work }\end{array}$ & 8 & 2.7 & $\begin{array}{l}\text { Unspeci- } \\
\text { fied }\end{array}$ & $29 \quad 9.9$ \\
\hline Price list & 4 & 1.4 & & & & $\begin{array}{l}\text { Use of } \\
\text { machinery }\end{array}$ & 1 & 0.3 & & \\
\hline $\begin{array}{l}\text { Methods of } \\
\text { payment }\end{array}$ & 3 & 1.0 & & & & & & & & \\
\hline Total & 176 & 59.8 & & 39 & 13.2 & & 31 & 10.5 & & $48 \quad 16.4$ \\
\hline
\end{tabular}

Source: See text for discussion of sources.

flowed freely, making the task of unravelling causation exceptionally complex. Furthermore, even as a dispute wore on there was no certainty that the issues initially at stake would remain the same. What began as a wage claim, for example, could be transformed into a dispute over the victimization of unionists or the employment of blacklegs. Finally, in practice disputes often had multiple causes, as the example of the builders' strike over hourly payment in I86I, discussed below, makes clear. Determining the primary, as opposed to contributary, cause is by no means easy. At the risk of oversimplification, however, disputes can be classified into three broad categories relating to questions of wages, control of the labour process and the employment of unskilled labour. A fourth group refers to disputes which either do not fit neatly into these three categories or for which the causes were not stated. Table 3 lists in more detail the separate issues included under each category together with their frequency.

At a general level the frequency of wage-related disputes reflects the shift from customary methods of negotiation, including arbitration by local magistrates over price lists and rates of pay, to the language of money and the dictates of the market. Steep inflation during the Napoleonic wars, which rapidly eroded customary rates of pay and rendered wage negotiations obsolete after a very short period of time, accelerated this shift. At a finer level of detail, however, the interpretation of wage disputes is more problematic. The critical issue was the extent of the rise or reduction in relation to the movement of retail prices. Strikes for increased pay that merely kept pace with prices were somewhat different from those in which a real increase over and above inflation was being sought. Although both related to an increase in wages, the first could be classified as a defensive action whilst the latter was more aggressive in nature. Conversely, when prices were falling, resistance to wage cuts that were less than the reduction in prices could be interpreted as an aggressive action, whereas disputes that tried to prevent wages falling faster than prices were of a more defensive nature. For 
example, the two major outbursts of wage-rise disputes in 1825 and 1853 both took place at times of rapid inflation. The steep price in 1825 prompted strikes by barge builders, carvers, coopers and shoemakers, all of whom sought increases that did no more than keep pace with inflation. ${ }^{78}$ The wave of strikes in 1853 similarly followed a 20 per cent rise in the price of bread and even greater increases in the cost of meat and other provisions. Set against these increases, wage claims were modest, asking in the most part for little more than a Io per cent rise. Builders, for example, struck for an increase of $6 d$ per day and shorter hours, which was equivalent to a rise of about Io per cent. Rugmakers, shoemakers, coal porters, lamplighters, dock labourers and the normally acquiescent East End slopworkers all struck for similar amounts. Even police constables petitioned the Home Office for an increase in pay. ${ }^{79}$ As the dock workers explained: "We only ask for what we consider ourselves justly entitled to, namely such an advance in wages as will enable us to maintain our wives and families in comfort, and fairly and honestly pay our way, as we have always endeavoured to do." ${ }^{\text {" }}$ As the dockers' example makes clear, the significance of wage disputes can only be judged in relation to price movements and to ignore this fact is to invite the misinterpretation of motives.

Before leaving the issue of wages, we need to pay attention to related disputes over the method of payment. Although this was a relatively minor cause of conflict, nevertheless the issues relating to forms of pay were crucial for understanding the links between payment, control of the labour process and status at the workplace. ${ }^{8 \mathrm{I}}$ In particular, the shift from time wages to piece-work and from weekly or daily wages to payment by the hour were of greatest significance. In both cases the most important aspect, as workers themselves recognized, was not the fact that wage cuts might ensue as a result of the change but that alterations to the methods of payment were generally accompanied by parallel transformations of the labour process. For example, the tendency for masters to adopt piece-work in place of a daily rate of pay was an important issue in the tailors' strike in 1834. This was objectionable primarily because it provided opportunities for the spread of subcontracting and the employment of cheap, domestic outworkers in place of skilled male artisans. ${ }^{82}$

The builders' dispute over hourly payment further illustrates this point.

78. Journeymens and Artizans London and Provincial Chronicle, I2, I9 June 1825; Artizans London and Provincial Chronicle, I0, 24 July, 28 August 1825; Trades Newspaper, 17, 31 July I825; Place Coll. Add. MS, 27803, f. 215; ibid., Add. MS 27805, ff. 365-372; Webb Coll. E, series A, vol. Io, f. 57 .

79. Reynolds Newspaper, 8, 29 May, I2, I9 June, IO, I7, 24 July, 7, I4, 2I August, 4, II, I8, 25 September I853; The Times, 27 July, I7 August, 9, 16, 23 September 1853.

80. The Times, 28 July 1853.

8I. See Peter Linebaugh, The London Hanged (London, 1993), pp. 438-44I.

82. Pioneer, 3, Io May 1834; British Library Place Newspaper Collection, vol. 5I, pp. 243-25I. For a fuller account of the strike and the events leading up to it see Parssinen and Prothero, "The London Tailors' Strike". 
In I86I when large building firms introduced hourly pay in place of a daily rate, workers struck throughout the city. Their grievances were not about the proposed hourly rate itself, which potentially offered higher returns to labour, but rather the fact that it increased the insecurity of employment. Building workers hired by the day received payment even if inclement weather or stoppages in production occurred. Hourly payment threatened to disrupt this arrangement because workers would only be paid for the amount of time actually worked. Hourly hiring was thus interpreted as a clear attack on artisan status, reducing journeymen to "the level of dock labourers". ${ }^{83}$ As the builders' leader, George Potter, remarked, "The hour system destroys a recognized day and is pernicious in its influence; in one word the fruits of the hour system are long hours of labour, over production and less pay." ${ }^{84}$ According to Potter, it would inevitably "lower the standard of respectability among workmen by degrading them to the level of those who earn their money by the most precarious means, and who have not received the training and education which every mechanic should receive" ${ }^{85}$ Pay itself, therefore, was not the sole concern but rather the impact that altered methods of payment had on the nature of employment and status at the workplace.

The question of wages was one issue amongst several that underlay industrial conflicts during the period. In the overstocked metropolitan labour market, the employment of cheap unskilled labour was, if anything, a greater threat to artisans' livelihoods and it is therefore of little surprise that it formed the second largest category of disputes. As Edward Thompson remarked in relation to London, "The pressure of the unskilled tide, beating against the doors, broke through in different ways and with different degrees of violence. ${ }^{" 86}$ Table 3 shows that employment issues, relating to the replacement of skilled by less skilled or unskilled labour, apprentices, improvers, learners, women and children, and non-unionists or "foul" men, accounted for 13 per cent of the total number of disputes. The precise circumstances relating to the employment of unskilled labour depended on the characteristics of individual trades. Where a basis of skill was retained, as in engineering and printing, the excessive use of apprentices was a constant source of contention. In clothing, male artisans objected to the employment of women, whilst the influx of female learners and improvers in bookbinding was also the cause of several disputes. Where powerful unions existed, such as amongst hatmakers in the early I80os, the employment of non-unionists or "foul" men was always likely to prompt a dispute. ${ }^{87}$

83. The Times, is July I86I.

84. Reynolds Newspaper, 2 June I86I.

85. Ibid., I3 October I86I.

86. Thompson, Making of the English Working Class, p. 279.

87. See Green, Artisans to Paupers, pp. I2I-I25, I28, I30; Hunt, British Labour History, pp. 7I-93;

Barbara Taylor, Eve and the New Jerusalem (London, I983), pp. IOI-II7. 
Though less important in terms of numbers, nevertheless such employment-related disputes were often amongst the hardest fought battles. For example, the bookbinders' strike of 1838 against large firms which employed excessive numbers of apprentices and learners continued for nearly nine months before a compromise was reached. ${ }^{88}$ Such bitter disputes emphasized the real threat posed to many traditional London trades by the greater use of cheap labour.

The third category of disputes related to control of the labour process and focused mainly around alterations to the hours of work, shorter hours, the introduction of machinery, and more general changes in the methods of work, such as speed ups or encroachment on trade privileges. In view of the chronic underemployment that characterized many London trades, the short time movement was of particular concern, notably following the high unemployment of the I840s. The opinion voiced by London Chartists at the I848 convention that one-third of workers were employed, another third only half-employed and the remainder unemployed was echoed by Mayhew in the Morning Chronicle. ${ }^{89}$ Various ways of dealing with the problem, including emigration, home colonization, cooperative production and local boards of trade to regulate prices, wages and competition, were voiced at the time..$^{90}$ However, as a means of combating the "redundancy of labour", the most immediate issue in terms of workplace disputes was the call for shorter hours.

Unlike rates of pay, which was a potentially divisive issue not only between London workers and those elsewhere, but also between groups of workers in the same trade, as the shoemakers discovered in I8I2, shorter hours was an issue which could draw together workers from a variety of trades in a more or less coordinated manner. The builders, who were in the forefront of the short hours campaign, had first argued for early Saturday closing in I847. The same issue provoked a series of minor disputes in I85I that culminated in a strike by over I,OOO masons against Jay and Myers, two of the largest firms in the capital. ${ }^{9 \mathrm{I}}$ Although a fall in building activity in the mid-I850s temporarily dampened enthusiasm for a fight, the issue rumbled on. ${ }^{92}$ In 1859 carpenters and masons resumed their call for a ninehour day, thereby prompting a lock-out of 20,000 men by the Central

88. The Times, I0 January I839; Operative, I3, 20 January, I7 February, 3I March, I4, 28 April, 5 May, 2 June I839; Northern Star, I8 May I839; T.J. Dunning, "Some Account of the London Consolidated Society of Bookbinders", in Trades Societies and Strikes, National Association for the Promotion of Social Science (I860), p. IoI.

89. Northern Star, 24 April I848.

90. Ibid., 27 May I848, Io March, 7 April, I2 May, io November I849, 2, 9 March, 20 July I850. 9I. Ibid., 25 October, I5 November I85I; Builder, I November, 27 December I85I; PP I867 XXXII, Royal Commission on the Trade Unions, q. I422.

92. Reynolds Newspaper, 23 November 1856. 
Association of Master Builders. ${ }^{93}$ Although the outcome on that occasion was inconclusive, the short hours movement gathered momentum and in the I86os began to draw support not only from the building workers but also from other trades including bakers, shoemakers, packers, brass finishers and railway signalmen. ${ }^{94}$ Indeed, as prices fell and real wages rose it became more difficult to argue for higher money wages, and for this reason issues relating to shorter hours of work became more important.

Finally, we should take note of technological change as a source of industrial conflict. Although machine breaking was not unknown in London, the use of machinery rarely led to disputes, primarily because technological change was of relatively little importance in many London trades and was therefore not seen as a major threat to employment or working conditions. That is not to say that technological change was unimportant as a cause of individual labour disputes: where machinery was introduced, such as in bookbinding in the late I820s and I830s, and in sewing in 1853, conflicts occurred but rarely resulted in violence. ${ }^{95}$ Stories of attacks against horsedriven saw mills during the downturn of the late 1820 s were recounted many years later by workers interviewed by Henry Mayhew, but these were exceptions rather than the rule. ${ }^{96}$ The outburst of silk cutting and loom smashing in Spitalfields in I829 was also somewhat exceptional, reflecting less antipathy towards machinery than fierce opposition to undercutting masters who took advantage of the weavers' desperate situation to reduce prices. ${ }^{97}$ Compared to other causes of conflict relating to the labour process, technological change was therefore of limited importance.

\section{CONCLUSION: GREAT CITIES, LABOUR AND \\ INDUSTRIAL CONFLICT}

Labour disputes were amongst the most frequent and disruptive forms of working-class protest. "No week passes, scarcely a day, indeed, in which there is not a strike in some direction", Frederick Engels wrote, "now against a reduction, then against a refusal to raise the rate of wages, again by reason of the employment of knobsticks, or the continuance of abuses, sometimes

93. Ibid., 3I July, 7, I4 August I859, I9 February I860; Shaw Lefevre and Bennett, "Account of the Strike and Lock-out in the Building Trades”, pp. 60-72; Samuel Smiles, Workmens' Earnings, Strikes and Savings (London, I86I), pp. I66-167; Webb Coll. E, series A, vol. II, f. I45. This dispute is dealt with in detail by Price, Masters, Unions and Men, pp. 45-53.

94. Reynolds Newspaper, 26 August, I4 October 1860, 22, 29 October 1865, 30 September 1866.

95. Ibid., 2 October 1853 . Although much bookbinding was still done by hand, machines were used in some of the larger binderies: see George Dodd, Days at the Factory (London, I843), pp. 363-384; Reply of the Journeymen Bookbinders (London, 1831).

96. Trades Newspaper and Mechanics Weekly Journal, 23 July, I7 September I826, 7, 28 January, 4 March I827; Mayhew, Morning Chronicle Survey, vol. 5, pp. 74-78.

97. Weekly Free Press, 6 June 1829. 
against new machinery, or for a hundred other reasons. ${ }^{998}$ Strikes brought hardship, divided communities and soured relations between employers and workers, and as such were rarely if ever undertaken lightly. But how important were such disputes in understanding the commodification of labour under industrial capitalism and how can they shed light on the relationships between place and social protest?

James Cronin has argued that "the strike truly came into its own as a form of collective organization in the I870s" and that until then strikes were "far more defensive in character and less successful than after that date".9" The 294 disputes which occurred in London between 1790 and 1870 suggest that strikes were perhaps more common than Cronin suggests, and in some ways more complex than he is willing to acknowledge. From the start of the period, and in all probability from much earlier, the strike was seen as a legitimate means of redressing grievances at the workplace. Not all strikes prior to 1870 were defensive, however, and from mid-century, when expansionary conditions provided a stronger basis for working-class action, disputes were often of a more "aggressive" nature. However, rarely if ever were strikes in London used as a way of pressing political claims or seen as a challenge to capitalist notions of property. Indeed, the overwhelming importance of wage-related disputes suggests a clear acceptance of the cash nexus between workers and employers. In this sense strikes and other forms of labour dispute reflected the conservative horizons of London workers and rarely took on a more radical tinge that posed a direct challenge to capitalist social relations.

Whilst the quantitative significance of strikes in London should not be underestimated, it is important to set it in the context of nineteenth-century cities as a whole. Eric Hobsbawm has argued, along with others, that conditions in the larger metropolis were not conducive to the organization of labour, particularly in the period before the availability of cheap, mass tran-

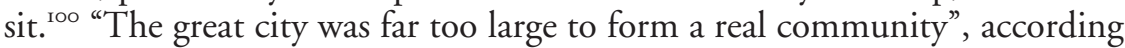
to Hobsbawm, and London in particular was too diverse for shared interests to overcome the problems of size. ${ }^{\text {ror }}$ To some extent this situation is reflected in the relationship between strikes and the urban hierarchy. Lynn Lees's work on Lancashire, Yorkshire, Leicestershire and Nottinghamshire in the later nineteenth century shows that strikes were relatively less common in larger cities compared to medium and small sized towns. In Lancashire, for example, cities with populations of at least 300,000 had strike rates of 9.I per IOO,000 people compared to 26.7 for places with between 20,000 and IOO,000 persons. Her explanation of this difference rests on the view that

98. Engels, Condition of the Working Class in England, p. 230.

99. Cronin, "Strikes I870-1914", p. 75.

Ioo. Eric Hobsbawm, "Labour in the Great City", New Left Review, I66 (1987), pp. 4I-42.

IOI. Ibid., p. 44. 
larger cities were more socially complex and less homogeneous than smaller places and consequently were less conducive to the development of cohesive working-class communities. ${ }^{\text {IO2 }}$

Even allowing for much lower recorded number of strikes earlier in the century, the strike rate in London fell far below these figures. Based on the evidence presented here, during the 1850 and 1860 s the strike rate per decade was in the region of $\mathrm{I} .9$ and I.8 per I00,000 population respectively. ${ }^{103}$ Although these figures must be treated with extreme caution, nevertheless the evidence hints that London workers were apparently reluctant to strike. This suggestion is lent weight by reference to other evidence. For example, in 1842 the General Strike passed virtually unnoticed in the capital whilst in $\mathrm{I} 888$, at the height of unskilled unionism, the proportion of workers directly involved in strikes in London was far lower than that in the north-east and north-west. ${ }^{\mathrm{I} 4}$ Such low levels of labour militancy can be explained with reference to the structure of the labour market and the geography of the city. The existence of large numbers of small firms not only held out the possibility of social mobility but also fostered close personal contact between employers and journeymen, thereby reducing potential conflicts between capital and labour. Whilst large firms were by no means absent from the capital, and indeed were often the focus for conflict, nevertheless the flexibility of the metropolitan economy provided workers with numerous opportunities for self-employment that helped to dampen any potential conflicts between capital and labour. ${ }^{\text {Ios }}$ This may have been particularly true for the first half of the century, when the capital required to enter many, though not all, trades was still relatively small.

Despite questioning the importance of London in relation to other regions, we should not underestimate the significance of neighbourhood and locality in the city in terms of labour disputes. Traditionally, labour history has been written from the viewpoint of trade unions and organized labour, but recent work has emphasized the role of neighbourhood and community in fostering working-class action. ${ }^{\text {I06 }}$ Whilst nineteenth-century London may have been socially fragmented, this did not preclude the existence of cohesive working-class neighbourhoods which in turn provided a strong basis for social protest. Over and above an artisan elite, semi-skilled

I02. Lees, "Strikes and the Urban Hierarchy in English Industrial Towns", pp. 52-73.

I03. This rate is based on the total number of strikes and lock-outs per decade divided by the estimated population at mid-decade.

104. See Charlesworth et al., Atlas of Industrial Protest in Britain, pp. 57, 70.

I05. For discussion of the role of large firms and labour market flexibility, see David R. Green, "The Nineteenth-Century Metropolitan Economy: A Revisionist Interpretation", London Journal, 2I (1996), pp. 9-26; Paul Johnson, "Economic Development and Industrial Dynamism in Victorian London", London Journal, 2I (I996), pp. 27-37.

Io6. See, for example, Lis and Soly, "Neighbourhood Social Change in West European Cities", pp. 25-30. 
and unskilled workers, including casual workers in the docks, were willing and able to embark on costly and sometimes protracted disputes. The ability to sustain such disputes was based as much on the existence of strong, working-class neighbourhoods, fostered by the localization of trades within London and underpinned by restrictions on spatial mobility arising from the lack of public transport, as on the existence of formal trade unions. ${ }^{107}$ The lesson to be drawn is that the significance of locality should not be underestimated by labour historians or indeed by those interested more widely in social protest. ${ }^{108}$

Given the broad scope of this paper, inevitably many of the issues raised above have been given less attention than they deserve. However, the objective here has been to provide a systematic analysis of labour disputes rather than a detailed discussion of their broader significance in understanding working-class history. In so far as this author is aware, the evidence discussed here provides the most comprehensive examination of labour disputes in any major British city of the period. As such, this paper can hopefully serve as a benchmark for further research at both national and regional levels and can act as a yardstick against which the findings of others can be gauged. ${ }^{\text {I09 }}$

\section{APPENDIX 1}

\section{Newspapers (years consulted)}

Artizans London and Provincial Chronicle (later Journeymens and Artizans London and Provincial Chronicle) (1825)

Beehive (I867-I870)

Cobbett's Annual Register (I802, I8Io)

Craftsman (I80I)

Crisis (I832-1834)

Drakards (later the Champion) (1813-1815)

East London Observer (I857-I86I, I866-I867)

Examiner (1817)

Gorgon (I8I8-1819)

Lloyd's Evening Post (1795)

London Chronicle (1798-1802)

I07. For discussions of working-class communities and residential mobility in London, see David R. Green, "Distance to Work in Victorian London: A Case Study of Henry Poole, Bespoke Tailors”, Business History, XXX (1988), pp. I79-194; idem, Artisans to Paupers, pp. 9I-94; David R. Green and Alan Parton, "Slums and Slum Life in Victorian England: London and Birmingham at Mid-Century", in Martin Gaskell (ed.), Slums (Leicester, 1990), pp. 76-82.

I08. This theme is explored further by Craig Colhoun, "Class, Place and the Industrial Revolution", in Nigel Thrift and Peter Williams (eds), Class and Space (London, 1987), pp. 5I-72; Michael Savage, The Dynamics of Working-Class Politics (Cambridge, 1987), p. 40. I09. The author is pleased to supply a printout of labour disputes on request. 
London Dispatch (1836-I837)

London Mercury (I836-I837)

London Packet (1795, 1800)

Morning Chronicle (1849-1850)

National Cooperative Leader (I86I)

Northern Star (later Star of Freedom) (I838-1852)

Operative (1838-1839)

Penny Papers for the People (I83I)

Pioneer (I833-I834)

Poor Man's Guardian (I83I-I835)

Radical (1836)

Red Republican (1850)

Reynolds Newspaper (185I-I868)

St James Chronicle (180I-1815)

Statesman (1809-1812, I820)

Tailor (I866-I867)

The Times (1790-1870)

Trades Free Press (1827-I828)

Trades Newspaper (1825-I827)

True Briton (1795-I799)

Weekly Free Press (1828-1829)

Weekly True Sun (1836-I837) 